\title{
Halina Postek
}

(Warszawa)

\section{MUSARYZM: MIĘDZY CHASYDYZMEM A HASKALĄ}

DOI 10.14746/SEG.2014.9.9

\section{Abstract}

The aim of paper is to acquaint Polish readers with the little known religious and ethical movement which developed in the latter half of the $19^{\text {th }}$ century in Lithuania. Associated with traditional Judaism, the Musar movement was to be an alternative both to Chasidism and the Haskalah.

Key words

Musar, Chasidism, traditional Judaism, Mitnagdim, Haskalah 
Hebrajski termin musar, utworzony od rdzenia jasar, „karać”, znaczy chłosta, ale także upomnienie. Użyty w Księdze Przysłów (Przypowieści Salomona) w polskim tłumaczeniu oddany przez „karność”, stał się nazwą własną ruchu etyczno-religijnego powstałego w XIX wieku w środowisku ortodoksyjnych Żydów Europy Środkowo-Wschodniej, a dokładniej - Żydów litewskich. Termin miał w różnych okresach rozwoju języka hebrajskiego kilka, nieco odmiennych znaczeń. W Tanachu używany był najczęściej w znaczeniu „dać/odebrać lekcję", jako konsekwencję niestosownego, niemądrego zachowania. Lekcja ta była zwykle interpretowana jako boska kara. W Septuagincie słowo to oddano greckim terminem paideia. O ile w biblijnym hebrajskim musar oznacza różne środki nauczania (od kary do słownej instrukcji), w hebrajskim rabinicznym musar znaczy stosowne zachowanie, moralność. Termin stosowany był w tradycji żydowskiej na określenie ruchów nakazujących zintensyfikowanie wysiłków służących pogłębieniu pobożności.

W 1842 roku Izrael Lipkin, zwany Salanterem, założył w Wilnie skierowany do żonatych mężczyzn kolel, gdzie gromadzący się w szabat kupcy mieli rozważać kwestie etyczne. Była to pierwsza z litewskich szkół, w której do programów nauczania włączono studiowanie lektur dotyczących praktycznej pobożności - musar. Lipkin chciał połączyć tradycyjne wartości judaizmu — studiowanie Tory i przestrzeganie micwot $-\mathrm{z}$ indywidualistycznie pojmowanym doskonaleniem się jednostki w sferze etycznej. Pomimo początkowych oporów, program Salantera przyjęty został w głównych uczelniach talmudycznych Litwy: Mirze, Słobódce, Telszach, Kielmach, Nowogródku. Musaryzm pojawił się na Litwie w połowie XIX wieku i ani miejsce, ani czas powstania tego ruchu etyczno-religijnego nie były przypadkowe. Poprzedzający go wiek XVIII uważany jest za przełomowy w historii diaspory Żydów Europy Wschodniej. Kryzys, $\mathrm{w}$ jakim znalazł się wówczas tradycyjny judaizm, spowodowany był przede wszystkim upadkiem autorytetu instytucji społecznych, takich jak kahał i rabinat, a bezpośrednio rozwiązaniem w 1764 roku Sejmu Czterech Ziem (Wa ad Arba Aracot) ${ }^{1}$.

Inną - może ważniejszą przyczyną - były herezje sabataistyczne, które w XVII wieku doprowadziły do głębokich podziałów społeczności żydowskiej (także w Polsce, za sprawą Jakuba Franka). Kryzys społeczno-ekonomiczny, kryzys duchowy (zostawiając na boku rozważania, co jest skutkiem, a co przy-

${ }^{1}$ J. Doktór, Formowanie się chasydyzmu polskiego, [w:] M. Galas (red.), Światło i słońce. Studia z dziejów chasydyzmu, Kraków 2006, s. 50. 
czyną), kryzys tradycyjnych wartości, na których opierały się relacje społeczne², niezdolność do sprawowania przywództwa przez rabinów, spowodowały rozczarowanie tradycyjnymi formami religii. Duchową próżnię wywołaną kryzysem wypełnić miał z jednej strony chasydyzm, z drugiej - haskala.

Pojawienie się chasydyzmu, mistycznego ruchu o charakterze mesjańskim, krótko po herezji Jakuba Franka i Sabataja Cwi, wywołało silny opór środowisk tradycyjnych. Podstawy teologiczne chasydyzmu także wzbudzały niepokój: przekonanie, że „każdy Żyd, bez względu na to, kim jest, może poznawać, że Bóg dosłownie napełnia wyższe i niższe światy, tak że Jego chwała dosłownie wypełnia wszechświat" ${ }^{\prime \prime}$, naruszało przez wieki utrwaloną praktykę religijną, nakazującą tym, którzy chcieli wypełniać Boże przykazania, studiowanie Tory i Talmudu i wypełnianie micwot. Początkowo działalność twórcy (czy raczej osoby uznanej przez późniejszą tradycję za twórcę ruchu) chasydyzmu polskiego Izraela ben Elezera (Baal Szem Towa, Beszta) skierowana była do pietystycznych elit, dopiero w końcowym okresie życia Beszt zaczął znajdować zwolenników poza tymi grupami. Zwolennicy Beszta kultywowali zwyczaje innych grup kabalistów i mistyków tego okresu: przyjęli sefardyjską wersję siduru z uzupełniającymi komentarzami XVI-wiecznego kabalisty Icchaka Lurii, oczyszczali się regularnie w mykwie i używali dwustronnie szlifowanych noży do uboju rytualnego. To, co zaproponowali nowego w sferze kultu, dotyczyło odnowy religijnej, polegającej na ekstatycznej żarliwości w modlitwie, rozszerzenia studiów tekstów żydowskich o kabalistyczną literaturę etyczną i przyjęcia nowego rodzaju przywództwa (cadycy). Na tym etapie ruch chasydzki, praktycznie ograniczony do wąskich grup i wąskiego obszaru kraju, nie wywoływał żadnych krytycznych reakcji. Sytuacja uległa zmianie, kiedy po śmierci Izraela ben Eliezera jego uczniowie rozpoczęli rozpowszechnianie nauk Beszta poza Podole: w zachodniej Galicji, centralnej Polsce, Białorusi i na Litwie.

W 1772 roku rozpoczęła się regularna kampania skierowana przeciwko chasydyzmowi. Prawdziwą przyczyną ataków był lęk przed powtórzeniem się rozłamu w społeczności żydowskiej, podobnego do tego, którego dokonał Jakub Frank, odwołujący się, podobnie jak Baal Szem i jego uczniowie, do tradycji mesjańskich. Swoje znaczenie miały też kwestie ekonomiczne. Do tych powodów dołączył się konflikt personalny pomiędzy dwoma najważniej-

\footnotetext{
${ }^{2}$ R. Elior, Mistyczne źródła chasydyzmu, Kraków-Budapeszt 2009, s. 14.

${ }^{3}$ Sznuer Zalman z Ladów, Tanja, 120, cyt. za: R. Elior, op. cit., s.132.
} 
szymi w tamtym okresie autorytetami religijnymi i moralnymi ${ }^{4}$, Eliachu ben Solomonem Zalmanem (zwanym Gaonem Wileńskim), stojącym na czele przeciwników chasydyzmu, a Dow Berem z Międzyrzecza (noszącym przydomek Wielkiego Magida), po śmierci Beszta uważanym za jego następcę. Obaj aspirowali do roli przywódcy polskiego żydostwa tamtych czasów. Na Litwie wpływy Gaona były silniejsze, a w Polsce centralnej i południowo-wschodniej większym poparciem cieszył się Dow Ber. Wielki Magid rozpoczął jednak akcję popularyzacji chasydyzmu i wysłał swych emisariuszy na Litwę, co wywołało niezadowolenie Gaona. Zimą 1771/1772 roku w Szkłowie doszło do dyskusji pomiędzy zwolennikami Gaona i Magida, w efekcie której stronnicy Gaona obłożyli przeciwników klątwą mniejszą — niduj. W tym samym 1772 roku dokonał się pierwszy rozbiór Polski, wskutek którego wspólnota polskich Żydów, żyjących do tej pory w jednym państwie, znalazła się w granicach czterech państw, prowadzących różną wobec nich politykę. . W roku 1772 umiera także rywal Gaona - Magid z Międzyrzecza. Te wydarzenia powodują wyciszenie sporu na kilka lat, aż do roku 1780, w którym ukazał się napisany przez Jaakowa Josefa z Połonnego traktat „Toldot Jaakow Josef” („Kroniki Jakuba Józefa”). W 1785 roku rabini najważniejszych kahałów litewskich zebrani w Zelwie koło Grodna ogłosili cherem (klątwę większą) na chasydów. Zakazano jakichkolwiek kontaktów z nimi, a przywódców zmuszono do opuszczenia Litwy. Poza Litwą do nowej kampanii odniesiono się jednak z dużą rezerwą, choć tekst cheremu został odczytany w synagodze w Krakowie. Na Ukrainie i w Polsce centralnej ruch chasydzki rozwijał się bez większych przeszkód.

Paradoksalnie, ataki na nowo formujący się ruch, zawarte w pismach adwersarzy chasydyzmu, wzmocniły jego tożsamość, a konieczność odpowiedzenia na zarzuty przyczyniła się do krystalizacji doktryny. Obraz jednego nauczyciela (Beszt) i jednej nauki chasydzkiej (wbrew istnieniom wielu różniących się $\mathrm{w}$ konkretnych rozwiązaniach cadyków, z których nie wszyscy nawet byli uczniami Beszta) został powszechnie zaakceptowany. Wspólnoty chasydzkie odmienne pod wieloma względami - stylu życia, przynależności społecznej, duchowej orientacji - połączyła świadomość odnowy duchowej, mistycznego doświadczenia oraz charyzmatycznego przywództwa ${ }^{6}$. Można uznać za pewną

\footnotetext{
${ }^{4}$ Obaj zaliczani byli do „sprawiedliwego pokolenia” — „cadik hador” (zobacz J. Doktór, op. cit, s. 50).

${ }^{5}$ J. Doktór, Mesjanizm Żydów polskich, Teologia Polityczna 4, 2006-2007, s. 125.

${ }^{6}$ R. Elior, op. cit, s. 12.
} 
ironię historii fakt, że po upływie kilkudziesięciu lat od powstania chasydyzm rozpadł się na konkurujące ze sobą grupy, które wiodły ze sobą walki nie mniej zaciekłe od tych prowadzonych wcześniej z przeciwnikami ruchu, skupionymi wokół Gaona Wileńskiego ${ }^{7}$. Choć występował początkowo z pozycji radykalnych i innowacyjnych ${ }^{8}$, nie przekraczał chasydyzm granic halachy ${ }^{9}$. To pozwoliło mu po kilkudziesięciu latach od pojawienia się zyskać akceptację środowisk tradycyjnych. Po zaledwie jedno pokolenie trwającej walce z przeciwnikami, reprezentowanymi przez zwolenników Gaona - mitnagdim, chasydyzm stał się pełnoprawnym ruchem religijnym, mającym ogromny wpływ na kształtowanie tożsamości żydowskiej. Akceptacja chasydyzmu spowodowana była niewątpliwie niezwykłą popularnością ruchu oraz śmiercią najzacieklejszego przeciwnika - Gaona Wileńskiego (1797). Do rozpowszechnienia się ruchu przyczynił się „patent tolerancyjny” z 1789 roku, obowiązujący na terenie Galicji, i „Statut o urządzeniu Żydów” z 1804, dotyczący obszaru Rosji, zezwalające chasydom na ustanowienie oddzielnych minianów (grup modlitewnych) ${ }^{10}$.

Konflikt pomiędzy zwolennikami haskali (maskilami) a ruchem chasydzkim został uznany za jeden z najważniejszych sporów społeczności żydowskiej Europy Środkowej i Wschodniej wieku modernizacji ${ }^{11}$. Haskala, zapoczątkowana w pierwszej połowie XVIII wieku w Niemczech, miała ograniczony wpływ na społeczność Żydów środkowo- i wschodnioeuropejskich, przede wszystkim ze względu na specyfikę religijności aszkenazyjczyków i ich sytuację ekonomiczną. Podobnie jak ruch chasydzki, haskala na dawnych ziemiach polskich nie miała jednego oblicza, można jednak wskazać wspólne przekonania zwolenników haskali (program haskali zachodnioeuropejskiej nie różnił się zasadniczo od programu maskili polskich i rosyjskich) - emancypacja, równouprawnienie

\footnotetext{
${ }^{7}$ Próby ekskomunikowania chasydów z Przysuchy (między 1815 a 1825), prześladowania chasydów z Bracławia ze strony chasydów ze Sawrania (lata 30. XIX wieku) oraz najbardziej chyba spektakularne wojny między dworem Sądeckim a Sadagórskim; zob. D. Asaaf, Chasydyzm: zarys historii, [w:] M. Galas (red.), Światło i słońce. Studia z dziejów chasydyzmu, s. 32; A. Ciałowicz, Wojny chasydów arcyciekawe. Nowy Sącz - Sadogóra 1868-1869, Warszawa 2010.

${ }^{8}$ D. Asaaf, op. cit., s. 15.

${ }^{9}$ Od początku chasydzi bronili się przed zarzutami przekraczania halachy stawianymi im przez mitnagdim, wskazując na stosowanie podobnych praktyk w poprzednich wiekach.

${ }^{10}$ D. Assaf, op. cit., s. 20.

${ }^{11}$ M. Wodziński, Oświecenie żydowskie w Królestwie Polskim wobec chasydyzmu, Warszawa 2003, s. 11.
} 
i edukacja świecka. Maskili łączyło przeświadczenie, że sytuacja Żydów wymaga natychmiastowej zmiany, jej polepszenie możliwe jest tylko przez realizację wymienionych haseł, co wiązać się musi się z walką z niektórymi instytucjami tradycyjnego życia żydowskiego. Emancypacja i równouprawnienie możliwe były, zdaniem zwolenników haskali, jedynie pod warunkiem rezygnacji z separatyzmu, przyjęcia wartości uniwersalnych i modernizacji społeczności żydowskiej. Pierwsza krytyka chasydyzmu ze strony haskali ma miejsce w tym samym czasie, co ataki mitnagdim. Zarzuty stawiane w tym okresie chasydom przez maskili są podobne (arogancja, pijaństwo, obżarstwo, nieobyczajne zachowanie, mistyczne fantazje ${ }^{12}$ ) do zarzutów, którymi posługiwali się zwolennicy Gaona Wileńskiego. Dopiero dwadzieścia lat później opublikowane zostaną teksty maskili, atakujące ruch chasydzki jako przeszkodę w reformie tradycji i ładu społecznego. Dostrzegając w chasydyzmie pozytywne aspekty (krytyka tradycyjnego judaizmu), ich autorzy ${ }^{13}$ dowodzą, że próba reformy judaizmu nie powiodła się, a sam chasydyzm jest zaprzeczeniem religii naturalnej (postulat maskili) i kwintesencją antyracjonalnego judaizmu.

Stosunek maskili polskich do chasydyzmu był początkowo łagodniejszy niż do tradycyjnej ortodoksji - wynikało to prawdopodobnie z niedoceniania znaczenia i popularności ruchu chasydzkiego na ziemiach polskich. Nieco inny był stosunek do chasydyzmu maskili rosyjskich. Relacje misjonarzy angielskich z podróży po Strefie Osiedlenia (rok 1825) mówią o tym, że na tych terenach chasydyzm ma przewagę nad judaizmem rabinicznym, co, zdaniem sprawozdawców, odróżniało wyraźnie Rosję od Królestwa Kongresowego ${ }^{14}$. Znaczna przewaga ruchu chasydzkiego w Strefie Osiedlenia (i Galicji) powodowała gwałtowniejszą reakcję tamtejszych zwolenników haskali. Nie bez znaczenia były zaszłości historyczne - pierwszymi krytykami chasydyzmu byli wszak stronnicy Gaona Wileńskiego. Początek oświecenia żydowskiego na ziemiach polskich datować można na lata osiemdziesiąte i dziewięćdziesiąte XVIII wie$\mathrm{ku}^{15}$. O jedno pokolenie później pojawi się haskala w Rosji. Jednak jako widoczny ruch społeczny haskala zaistniała po powstaniu Królestwa Polskiego, co można tłumaczyć silnym związkiem ruchu z reformatorską (wobec Żydów)

\footnotetext{
${ }^{12}$ Cyt. za M. Wodziński, op. cit., s. 28.

${ }^{13}$ Salomon Majmon, Menachem Mendel Lefin i Jacques Calmanson (za: M. Wodziński, op. cit.), s. 118.

${ }^{14}$ Podaję za M. Wodziński, op. cit., s. 106.

${ }^{15}$ Ibidem, s. 46.
} 
polityką władz państwowych i powiązaniami maskili z aparatem urzędniczym. Podobne zależności da się stwierdzić pomiędzy maskilami rosyjskimi a władzą carską. Silny związek żydowskiego oświecenia z polityką władz carskich opierał się także na zaangażowaniu znaczącej liczby zwolenników haskali w program reform ludności żydowskiej ${ }^{16}$. Podobne były konsekwencje zbliżenia haskali i władzy na terenach Królestwa i w samej Rosji — powstanie żydowskiej, zasymilowanej inteligencji. Postulatem podstawowym, wysuwanym przez maskili zachodnio- i wschodnioeuropejskich, warunkującym powodzenie wszystkich pozostałych, był postulat reformy edukacji, rozumianej jako całość procesu wychowawczego. Haskalowy program oświaty opierał się na podziale edukacji na dwa obszary: wiedzę religijną i wiedzę świecką. Wiedza religijna rozumiana była jako nauka moralności, uzupełniona podstawami języka i gramatyki hebrajskiej, historii żydowskiej oraz klasycznej literatury religijnej. Znajomość Talmudu zredukowana być miała do znajomości maksym i najważniejszych zasad $^{17}$. Wiedza świecka obejmowała język narodowy, rachunki, astronomię, geografię, historię, rzemiosło i rolnictwo. Hasła haskali, związane z krytyką kahału i prowadzoną przez tradycyjne autorytety polityką separatyzmu, z wielką siłą uderzały w status quo. W uporczywym trzymaniu się rozwiązań, które odsuwały możliwość modernizacji, maskile widzieli przyczyny uniemożliwiające społeczności żydowskiej sprostanie wyzwaniom zmieniającego się świata i dołączenie do grup beneficjentów historycznych zmian. Kwestionowanie pozycji dotychczasowych autorytetów - instytucji kahału i rabinatu, odrzucenie tradycyjnej formy religijności - zbliżało początkowo maskili do chasydów. Jednakże propozycje zwolenników haskali szły, w ocenie sympatyków ruchu chasydzkiego, w kierunku asymilacji - i w konsekwencji, utraty tożsamości żydowskiej. Nie chodziło tylko o kwestie religijne: maskile nigdy nie poszli tak daleko w swoich postulatach, jak niektórzy przedstawiciele oświecenia europejskiego i nie odrzucali religii jako sprzecznej z rozumem. Ale ich postulaty walki $\mathrm{z}$ „zatwardziałymi fanatykami” uderzały w rabiniczny judaizm, tak samo jak w zwolenników kabalistycznych interpretacji, którymi byli chasydzi. Obawy chasydów nie były bezpodstawne: to z krytyki haskalowej bierze początek judaizm reformowany ${ }^{18}$, powstały jako „postępowa” wersja judaizmu, umoż-

\footnotetext{
${ }^{16}$ Taką samą politykę stosowały władze Galicji i Rosji.

${ }^{17}$ M. Wodziński, op. cit., s. 59.

${ }^{18}$ „Judaizm reformowany stał się bezpośrednim (już po upływie jednego pokolenia) efektem haskali, czyli żydowskiego Oświecenia (które trwało od lat 1770-tych do 1880-tych) i kwinte-
} 
liwiająca Żydom funkcjonowanie w nowoczesnym społeczeństwie. Stosunek maskili do chasydyzmu był początkowo podobny do stosunku mitnagdim wobec nowego ruchu. Wyraźnie wrogi charakter przybrała krytyka chasydyzmu w następnym pokoleniu maskili, choć teksty pisane wówczas przez zwolenników haskali świadczą o prawie całkowitej nieznajomości ruchu. W latach pięćdziesiątych dziewiętnastego stulecia liczba zwolenników chasydyzmu była obliczana już na jedną trzecią populacji Żydów Europy Środkowo-Wschodniej. Pozostałe dwie trzecie stanowili zwolennicy postępu i ortodoksji ${ }^{19}$. Chasydom, których liczebność systematycznie rosła, przypisywano większą niż pozostałym grupom aktywność i inicjatywę. Dzięki rosnącej liczbie zdobywali większość w strukturach kahalnych, a po likwidacji kahałów, w dozorach bóżniczych. Ten wzrost znaczenia stał się przyczyną, dla której maskile zobaczyli w chasydyzmie głównego przeciwnika $\mathrm{w}$ walce o modernizację, i skierowali swe ataki na lekceważony do niedawna ruch. Rosnący w siłę ruch chasydzki odpierał ataki maskili własnymi zarzutami, oskarżając zwolenników haskali o hedonizm, ateizm i libertynizm, lekceważenie tradycji i zwyczajów żydowskich. W latach sześćdziesiątych XIX wieku następuje widoczny podział wśród zwolenników haskali na rzeczników integracji i akulturacji oraz ich oponentów ${ }^{20}$. Rzecznicy integracji głosili tezę o nieistnieniu „narodu żydowskiego”, a pojęcie to zastąpili koncepcją „wspólnoty wyznaniowej”21. Solidarność wyznaniowa była powinnością religijną i zobowiązywała od momentu przekazania na Synaju Tory. Religia w tej koncepcji miała mieć charakter jednoczący, ale zarazem w oczach wielu zwolenników integracjonizmu jej funkcje były wyłącznie społeczne. Redefinicja judaizmu była jedną z przyczyn, dla których dotąd niechętne sobie środowiska tradycyjnych wyznawców, chasydów i mitnagdim zwarły szeregi. Obrona tożsamości żydowskiej, rozumianej przede wszystkim jako identyfikacja religijna,

sencją jego podstawowych założeń: akceptacja uniwersalnej wiedzy świeckiej i pełny udział w jej rozwoju oraz kształcenie i wychowanie młodzieży w duchu współczesnym. Oznaczało to m.in. wyjście z ghetta, zarzucenie izolacji od narodowości i środowisk nieżydowskich, całkowite przyswojenie sobie języków europejskich, integrację społeczną, intelektualną i ekonomiczną bez asymilacji rezygnującej z żydostwa. Wszystko to razem wzięte - i podkreślany w haskali postulat ograniczenia wpływu rabinów! — spowodowało natychmiastowy sprzeciw ortodoksów i większości rabinów, przybierający nieraz formy bardzo agresywne, a nawet gorszące, znane z wielu skandalicznych incydentów". Robert Stiller, http://refj.w.interia.pl/judaism01.htm, dostęp: 19.03.2013.

${ }^{19}$ M. Wodziński, op. cit., s. 135.

${ }^{20}$ Ibidem, s. 170.

${ }^{21}$ Ibidem, s. 27. 
była hasłem, pod którym zjednoczyli się dotychczasowi przeciwnicy. Maskilom zarzucano wyrzeczenie się wiary - przez nawoływanie do świeckiej edukacji, odrzucenie świętego języka hebrajskiego i zastąpienie go językami narodowymi, niechęć do tradycyjnego stroju i wyśmiewanie zwyczajów. W postulatach dostosowania do wyzwań współczesnego świata dostrzegano niebezpieczeństwo wyrzeczenia się dziedzictwa przodków, a w realizacji postulatów haskali prostą drogę do asymilacji. Trzeba przyznać, że obawy te były zasadne. „Na ogół badacze dostrzegają iunctim między procesem równouprawnienia i uobywatelnienia Żydów a szeroko pojętą asymilacją i integracją z innymi mieszkańcami danego kraju. Rozwój gospodarczy, przemiany społeczne i częstsze kontakty prowadziły do wyzwolenia się jednostek i całych grup z tradycyjnego sposobu życia, do akulturacji ze społecznością dominującą lub panującą warstwą, a w konsekwencji do odejścia od własnej tradycji, obyczajów, kultury a nieraz i do zupełnego wynarodowienia"22. Żydzi w nowych warunkach, które powstały w wyniku rozbiorów Polski, zmuszeni zostali do dokonania wyboru: rezygnacja z dotychczasowego stylu życia, w formie zupełnej asymilacji bądź częściowej akulturacji i integracji, albo opowiedzenie się za tradycją i wiarą przez przyłączenie się ruchu chasydzkiego.

Dla wielu wyznawców tradycyjnego judaizmu żadne z rozwiązań: ani propozycje zwolenników oświecenia żydowskiego, ani radykalne zmiany wprowadzone przez chasydów, nie były możliwe do zaakceptowania. Zrodziła się pilna potrzeba znalezienia rozwiązania kompromisowego: połączenia tradycji z nowoczesnością, odczytania na nowo doktryny, tak by zapobiec asymilacyjnym ruchom młodego pokolenia, nie pozostawiając mu jako jedynej alternatywy chasydyzmu. Było oczywiste, że odnowa życia religijnego musi dokonać się przez reformę edukacji. Postulat zmian w tradycyjnym szkolnictwie pojawił się prawie równocześnie w środowisku ortodoksyjnych Żydów Europy Środkowo-Wschodniej i w oświeconych kręgach inteligencji żydowskiej, popieranej przez władze państwowe, żywo zainteresowane rozwiązaniem „kwestii żydowskiej”. W 1826 roku, w Warszawie, z inicjatywy działaczy ruchu asymilatorskiego, na podstawie dekretu carskiego z 1825 roku, została otwarta Warszawska Szkoła Rabinów. Jej celem było kształcenie, według zreformowanego programu nauczania, lojalnych wobec władz państwowych rabinów i nauczycieli szkół żydowskich. Kilkanaście lat później, w 1840 roku, wileńscy maskile, w odpowiedzi

\footnotetext{
${ }^{22}$ A. Eisenbach, Emancypacja Żydów na ziemiach polskich $1785-1870$ na tle europejskim, Warszawa 1988, s. 15.
} 
na plany zmian w systemie oświaty zaproponowane przez ministra Uwarowa, wystosowali list zawierający, między innymi, postulat otwarcia szkolnictwa żydowskiego na nauczanie świeckie i zatrudniania w szkołach nowego typu nauczycieli wywodzących się ze środowiska zwolenników haskali ${ }^{23}$. W roku 1844 władze carskie uchwaliły dekret o rabinach prowincjonalnych, a ministerstwo oświaty zostało zobowiązane do kształcenia rabinów w specjalnych szkołach, objętych opieką państwa. W 1847 i 1848 roku otwarto państwowe szkoły rabinackie w Wilnie i Żytomierzu, a w 1855 roku wydano dekret o wyborach rabinów wyłącznie spośród absolwentów państwowych uczelni rabinackich. Próby reform spotkały się jednak z oporem środowisk ortodoksyjnych: w 1862 została zamknięta uczelnia warszawska, a w 1873 roku z powodu braku kandydatów zamknięto szkołę rabinacką w Wilnie.

Jeszcze przed założeniem pierwszych państwowych szkół rabinackich, w dostrzegających problem ortodoksyjnych kręgach litewskich Żydów zrodziła się idea przekształcenia jesziw w ośrodki kształcące i wychowujące wedle nowych wzorów osobowych. Inicjatorem zmian był Chaim z Wołożyna. Najwybitniejszy uczeń Gaona Wileńskiego, uznając, że tym, co odstręcza młodych ludzi od tradycyjnych studiów, są przestarzałe metody nauczania i złe warunki socjalne studentów, otworzył w 1803 roku w Wołożynie jesziwę nowego typu. Jesziwa wołożyńska była pierwszą niezależną finansowo od lokalnej gminy uczelnią żydowską. Utrzymywana ze składek, mogła pozwolić sobie na wprowadzenie zmian w programie nauczania: jednym z pierwszych kroków Chaima było odrzucenie uznanej za jałową metody pilpulu i zastąpienie jej odczytywaniem znaczenia tekstu.

Założyciel wileńskiego kolelu, Izrael Salanter, był nie tylko kontynuatorem idei Chaima z Wołożyna; był przede wszystkim twórcą nowego ruchu etyczno-religijnego. Głównym problemem, na którym koncentrował się musar, było pytanie o związek pomiędzy studiowaniem Tory i Talmudu a moralną doskonałością, przejawiającą się w codziennym zachowaniu, do której osiągnięcia wezwany jest człowiek ${ }^{24}$. Wyznaczenie każdej z tych aktywności właściwej pozycji, pokazanie wzajemnych zależności, było przedmiotem refleksji już w klasycznej tradycji rabinicznej. Ale kiedy w połowie XIX wieku Izrael Salanter podejmował ten temat, zrobił to przede wszystkim dlatego, by pokazać, że za-

\footnotetext{
${ }^{23}$ L.S. Eckman, The History of the Musar Movement, Inc, New York 1975, s. 51.

${ }^{24}$ I. Etkes, Rabbi Israel Salanter and the Mussar Movement. Seeking the Torah of truth, Philadelphia, Jerusalem, 5753/1993, s. 5.
} 
danie, jakim jest indywidualny rozwój każdej jednostki w sferze moralnej, możliwe jest do wypełnienia nie tylko w odrzucającym tradycyjne wartości - studiowanie tekstów i wypełnianie micwot - chasydyzmie. Do programów nauczania $w$ jesziwach zakładanych przez Lipkina dołączono studiowanie lektur dotyczących praktycznej pobożności. Zalecano prowadzenie specjalnych dzienniczków, w których notowane były przeżycia związane z lekturą. Studenci jesziw spotykali się na zajęciach grupowych, podczas których analizowali swoje zachowanie, omawiając swoje potknięcia i przewiny moralne. Odbywano cotygodniowe pogadanki na tematy moralne (musar szmues) prowadzone przez etycznego zwierzchnika (maszgiach). Celem praktyk było samodzielne przezwyciężenie wewnętrznych przeszkód na drodze samodoskonalenia. Czytano wybrane fragmenty $\mathrm{z}$ traktatów etycznych, wyodrębnione wypowiedzi z midraszy i Talmudu, wersety z Biblii służące do wytwarzania odpowiedniego nastroju i uczuć. Zalecano pracę nad pielęgnowaniem cnót, takich jak: prawdomówność, zaangażowanie, zdecydowanie, szacunek dla innych, wewnętrzny spokój, łagodna mowa, schludność, cierpliwość, zdyscyplinowanie, pokora, sprawiedliwość, oszczędność i milczenie. Tym, co w szczególny sposób interesowało Salantera, była rola motywacji psychologicznej dla życia religijnego — i tym samym - możliwości takich oddziaływań na emocje, by przyczyniły się one do osiągnięcia, pożądanego z punktu widzenia rozwoju etycznego, stanu yir'ah (bojaźni bożej). Musaryzm oparty był na ideach ascetyzmu i rygoryzmu moralnego. Można w nim dostrzec zarówno wpływy mistyczno-kabalistycznych pism Izaaka Lurii, jak i myśli chrześcijańskiej. Jednocześnie uderzająca jest współczesność rozwiązań wykorzystywanych w ruchu musar: techniki stosowane $\mathrm{w}$ pracy nad samodoskonaleniem wyprzedzają niektóre dzisiejsze techniki psychoterapeutyczne, a wyjaśnienia motywów postępowania antycypują Freuda. W języku współczesnej psychologii można nazwać metody stosowane $\mathrm{w}$ jesziwach musar ${ }^{25}$ : terapią grupową ( wa 'aad), indywidualnym doradztwem i coachingiem (maszgiach), nakierowanym na siebie programem edukacyjnym (musar seder), autosugestią (studiowanie w specjalnych miejscach - musar klojz - i przy użyciu szczególnych technik: czytano fragmenty tekstów do melodii wziętych z repertuaru magidów, stosownych dla wywołania nastroju emocjonalnej otwartości na Boga i jego przykazania, w półmroku

\footnotetext{
${ }^{25}$ M. Levin, Beyond Psychology. Musar of our Times, Jewish Action, Winter 5764/2003, http://printfu.org/read/musar-for-our-times-99da.html?f=1qeXpurpn6Wih-SUpOGul66nh7nk6cbmiMvf5Im96diVwc7Z1OmHr9ufoayL1Jah6KeaoqmYzejc1aqhmOXr3aPa2t_ i19fd1tjk293j6Muj3, dostęp: 19.03.2013.
} 
i przyćmionym świetle. W pewnym sensie przypominało to „ćwiczenia duchowe" zalecane przez jezuitę Ignacego Loyolę). Nauczyciele musar kładli wielki nacisk na indywidualne podejście do każdego studenta jesziwy, stosując wobec każdego inne, odpowiednie dla danego przypadku techniki pracy ${ }^{26}$. W niektórych jesziwach posługiwano się specyficznymi metodami: Kelm znany był z prac nad koncentracją, która służyć miała osiągnięciu samokontroli, w Nowogródku posługiwano się techniką birże („giełdy”) - rozmowy na temat lektur musar i ich zastosowaniu we własnym życiu odbywały się podczas spacerów, przy użyciu bogatej gestykulacji i okrzyków - tak jak na giełdzie. Zaproponowane przez Salantera i uzupełnione przez jego uczniów strategie pracy nad doskonaleniem własnego charakteru brały się z przekonania, że nasze codzienne zachowanie wypływa z pewnych właściwości duszy: z częścią z nich przychodzimy na świat, część nabywamy później. Każdy z nas stanowi specyficzną „mieszankę” owych właściwości - negatywnych, takich jak zazdrość, lęk, pożądanie, i pozytywnych: cierpliwość, hojność, wdzięczność, bojaźń boża. Wgląd w te „dyspozycje” naszej duszy i dokonywana nieustannie praca nad korektą naszego charakteru były celem ćwiczeń zaproponowanych przez Salantera. Musar nigdy jednak nie chciał być tylko psychologią — był pomyślany jako lekarstwo dla duszy: terapia (czy psychoterapia w dzisiejszej terminologii) - a nie psychologia teoretyczna. W odróżnieniu od współczesnej psychologii, musar zalecał kontrolę i kierowanie własnymi emocjami. Stosowane przez musar techniki odwoływały się wprost do działań na emocjach — jak na przykład śpiewanie wybranych fragmentów tekstu w celu wprowadzenia ich do podświadomości. Musar nie był też zainteresowany technikami wglądu w przeszłość - szukanie przyczyn własnych zachowań przez głęboką analizę przeszłości nie wydawało się konieczne - wszyscy mamy bolesne doświadczenia za sobą rzecz w tym, by umieć się wyzwolić z przeszłości. Punkt wyjścia musar był odmienny niż ten, przyjmowany przez psychologię: naprawa charakteru miała nastąpić nie tylko przez analizę własnego postępowania, ale także - a może przede wszystkim, przez zmianę zachowania. Zmieniając zachowanie, zmieniamy także nasze nastawienie: nie tylko nasze myśli wpływają na nasze działania, lecz nasze działania oddziałują na nasze myśli. Celem ruchu było umożliwienie każdemu z nas wspięcia się na wyższy poziom, zgodnie z zaleceniem płynącym z Psalmu 1: Aszrej haisz (naprzód podąża człowiek) ${ }^{27}$. Środkiem

\footnotetext{
${ }^{26}$ Ibidem.

${ }^{27}$ Podaję za niepublikowanym tłumaczeniem rabina Sachy Pecarica.
} 
pozwalającym na osiągnięcie tego celu była przede wszystkim lektura tekstów religijnych. Prócz tradycyjnie studiowanych w jesziwach Talmudu i Humaszu, były to: traktat etyczny Mosze Chaima Luzzatto zatytułowany „Mesilat Jeszarim” („Ścieżka sprawiedliwych”), „Tikun Midot haNefesz” („Doskonalenie wartości moralnych”) Salomona ibn Gabirola i "Sefer Chesbon haNefesz” („Księga rachunku sumienia”) Menachema Mendla Lefina. Obecność na liście lektur pism etycznych XVIII-wiecznego kabalisty i mistyka Chaima Luzzatto nie dziwi. „Mesilat Jeszarim” znana była i ceniona już przez Gaona Wileńskiego. „Ścieżka sprawiedliwych” jest opisem drogi, jaką pokonać powinien każdy człowiek, chcąc uwolnić się od wewnętrznych przeszkód uniemożliwiających mu osiągnięcie poziomu świętości. Celem prawdziwej pobożności jest cieszenie się Ha-Szem i rozkoszowanie się jego Szechiną, a osiągnąć ten stan można, podążając wskazaną przez Luzzatto ścieżką. Traktat żyjącego w XI wieku Salomona ibn Gabirola, „Tikun Midot haNefesz”, wskazuje na ścisły związek między psychofizycznym podłożem funkcjonowania człowieka a jego życiem moralnym. Gabirola uważa jednocześnie, że można wpływać na swój charakter moralny przez zmiany dokonywane $\mathrm{w}$ dyspozycjach temperamentalnych. Obowiązkiem każdego człowieka jest uważna samoobserwacja i poddawanie korekcie własnych zachowań. To, że człowiek zdolny jest do takiej zmiany, jest prawdziwym błogosławieństwem i dowodem boskiej dobroci. Zaskakujące może się wydawać znalezienie się na liście lektur musar traktatu jednego z czołowych maskili polskich XIX wieku - Menachema Mendla Lefina ${ }^{28}$. Ten polski Żyd, pionier ruchu oświeceniowego, uczeń i przyjaciel Mojżesza Mendelssohna, jeden z pierwszych krytyków chasydyzmu, ale jednocześnie tłumacz szeregu utworów biblijnych na jidysz, jest autorem „Księgi rachunku sumienia”, napisanej pod wpływem programu moralnej samoodnowy, przedstawionego w „Autobiografii” Benjamina Franklina. Wydana w 1808 roku we Lwowie „Sefer Chesbon haNefesz" miała wiele wznowień - jedno z nich, z roku 1844, ukazało się z inicjatywy Salantera. Intencją Lefina było przedstawienie sposobów „naprawy charakteru” przez wytrwałą korektę wad. Praca nad samodoskonaleniem przebiegać miała według utworzonego przez osobę zainteresowaną planu. Pierwszym krokiem było sporządzenie listy 13 cnót (middot), rozwinięcie których pozwoliłoby pozbyć się usterek charakteru. Dla każdej z tych 13 cnót znaleźć trzeba było następnie stosowną maksymę, powtarzaną codziennie przez tydzień, podczas którego dana cnota była praktykowana. $\mathrm{Na}$

\footnotetext{
${ }^{28}$ Patrz: I. Etkes, ibidem, s. 123 i nn.
} 
cały rok składały się cztery trzynastotygodniowe cykle. Efekty ćwiczeń zapisywane być miały w specjalnych notesach. Metoda opisana przez Lefina jest niemal identyczna z przedstawionym przez Franklina w „Autobiografii” programem samodoskonalenia i niemal dokładnie taka sama, jak zaproponowana przez Salantera w jesziwach musar. Wspólne polskiemu maskilowi i litewskiemu reformatorowi było przekonanie, że edukacja etyczna jest procesem zainicjowanym, kierowanym i kontrolowanym przez intelek ${ }^{29}$, chociaż jednocześnie obaj przyznawali wielki wpływ na nasze zachowania nieuświadamianym siłom psychiki. Wspólna była oświeceniowa wiara, że człowiek jest w stanie zmienić swój charakter (swoją naturę) przez racjonalne metody działań.

Izrael Lipkin uważał, że jedynym zadaniem stojącym przed wychowawcą jest transformacja powierzonego jego pieczy wychowanka w mensza (żydowski termin, odpowiadający pojęciu „prawdziwego człowieka”), i że drogą wiodącą do tego celu jest, wbrew temu, co głosili chasydzi, studiowanie Tory i Talmudu oraz wypełnianie micwot. Był tym, który tchnął nowego ducha w tradycyjną żydowską edukację i pokazał, że można pogodzić cele haskali - reformę edukacji, z postulatami „pobożnych” — indywidualistycznie pojmowaną etyką.

\section{Podsumowanie}

Dzięki wysiłkom twórcy i propagatora ruchu musar wielu młodych ludzi oparło się ideom haskali, a tradycyjny judaizm wzbogacony został o duchowy wymiar, stanowiąc przeciwwagę dla chasydyzmu. Do dziś z ducha musaryzmu czerpią jesziwy odwołujące się do tradycji Żydów litewskich. Ale nie tylko one: od kilkudziesięciu lat jesteśmy świadkami odrodzenia idei Izreala Lipkina w Stanach Zjednoczonych. Setki, a może już tysiące osób, uczestniczy w rozmaitych programach nauczania musar. Powstały organizacje propagujące ruch, wydawane są książki ${ }^{30}$ zachęcające do wykorzystywania wskazanych przez Salantera metod i technik w pracy nad samorozwojem. Musar jest dziś dla wielu Żydów tym, czym był w początkach swego istnienia: drogą życia.

\footnotetext{
${ }^{29}$ Ibidem, s. 131.

${ }^{30}$ Zob. A. Morinis, Climbing Jacob's Ladder: One Man's Journey to Rediscover a Jewish Spiritual Tradition; idem, Everyday Holiness. The Jewish Spiritual Path of Musar.
} 


\section{Halina Postek \\ THE MUSAR MOVEMENT: BETWEEN \\ CHASSIDISM AND THE HASKALA}

\section{Summary}

The $19^{\text {th }}$ century is a watershed in the history of Jews in Central-Eastern Europe. The religious and philosophical-social movements of Chasidism and Haskalah come into existence in response to the crisis of traditional Judaism. After the initial clashes, adherents of traditional Judaism and the Chasidim unite their forces to repel the postulates of the Maskilim which, in their view, threaten the Jewish identity.

Founded on traditional Judaism, there appears a solution which is to be a compromise between Chasidism and Haskalah — the Musar movement. 